University of Nebraska - Lincoln

DigitalCommons@University of Nebraska - Lincoln

\title{
Similar bird communities across grazing systems in the Nebraska Sandhills
}

\author{
M. Sliwinski
}

\author{
L.A. Powell \\ University of Nebraska - Lincoln \\ W. Schacht \\ University of Nebraska - Lincoln
}

Follow this and additional works at: https://digitalcommons.unl.edu/natrespapers

Part of the Natural Resources and Conservation Commons, Natural Resources Management and Policy Commons, and the Other Environmental Sciences Commons

Sliwinski, M.; Powell, L.A.; and Schacht, W., "Similar bird communities across grazing systems in the Nebraska Sandhills" (2020). Papers in Natural Resources. 1398.

https://digitalcommons.unl.edu/natrespapers/1398

This Article is brought to you for free and open access by the Natural Resources, School of at DigitalCommons@University of Nebraska - Lincoln. It has been accepted for inclusion in Papers in Natural Resources by an authorized administrator of DigitalCommons@University of Nebraska - Lincoln. 


\title{
Similar Bird Communities Across Grazing Systems in the Nebraska Sandhills
}

\author{
MAGGI S. SLIWINSKI ID, ${ }^{\mathbf{1 , 2}}$ University of Nebraska-Lincoln, Box 90, McCord, SK SOH2TO, Canada \\ LARKIN A. POWELL, University of Nebraska-Lincoln, 419 Hardin Hall, 3310 Holdrege Street, Lincoln, NE 68583, USA \\ WALTER H. SCHACHT, University of Nebraska-Lincoln, 202 Keim Hall, Lincoln, NE 68583, USA
}

\begin{abstract}
Much of the remaining native rangeland in the Great Plains in the United States is privately owned and managed for beef production, and this single priority for land use may be contributing to declining avian biodiversity through a loss of structural heterogeneity. One proposed solution is to use multiple grazing systems across ranches, under the assumption that this approach will increase heterogeneity of vegetation structure and avian diversity across the landscape. We tested the relationship between grazing systems and avian diversity in the Nebraska Sandhills during 2014 and 2015 on a landscape that included 11 management units containing 5 different grazing systems. We used multivariate models to examine the relationship of bird diversity and communities to grazing systems at the management unit scale, and we used simulations to combine empirical data from $\geq 1$ grazing system into virtual landscapes to test the hypothesis that multiple grazing systems would result in greater heterogeneity. The 5 most common avian species made up $84 \%$ of observations (28 species), and songbird richness was $5-6$ species/ $7.06 \mathrm{ha}$ at $53 \%$ of our plots. Variation in each of the diversity measures (Shannon diversity range $=0.41-2.2$, Simpson's diversity range $=0.24-0.88$ ) was best explained by the previous dormant season's stocking rate, and richness declined by about 1 species/plot with an increase in 1 animal unit month (AUM)/ha. Songbird community structure showed the most variance between management unit, but grazing system explained little community variation. None of the simulated landscapes consistently had greater structural heterogeneity of visual obstruction reading, litter depth, and cover of bare ground than others, and there was a limited level of heterogeneity overall in the simulated landscapes. In contrast to our predictions, a variety of grazing systems did not increase heterogeneity of vegetation structure across the landscape. Thus, conservation practitioners should encourage the use of other strategies to create structural heterogeneity, such as prescribed fires and extreme stocking rates, which will support a diverse grassland songbird community (i.e., a greater variety of bird species) across the landscape. (C) 2020 The Wildlife Society.
\end{abstract}

KEY WORDS beef production, disturbance process, grazing systems, heterogeneity, songbird communities, stocking rates, vegetation structure.

Eighteen of 28 bird species listed in the grassland breeding group on the Breeding Bird Survey are in decline and the remaining 10 are not increasing (Sauer et al. 2017). Grassland birds have had the greatest proportional loss (53\%) of any group across breeding biomes (Rosenberg et al. 2019). Grasslands vary in vegetation structure, and species of grassland birds have evolved to use the variation in structure to their advantage. Although some species of birds are generalists within grasslands, these species generally require extremes of vegetation structure (e.g., high amounts of bare ground or high residual cover; With et al. 2008), such as horned lark (Eremophila alpestris) and grasshopper sparrow (Ammodramus

Received: 16 March 2019; Accepted: 12 December 2019

\footnotetext{
${ }^{1}$ E-mail: maggi.sliwinski@gmail.com

${ }^{2}$ Current affliation: Grasslands National Park, Parks Canada Agency, PO Box 150, Val Marie, SK SON2TO, Canada
}

savannarum). To support biodiversity and to recover bird populations, rangeland managers should ensure that large patches of different types of vegetation structure (i.e., structural heterogeneity) are present across intact rangeland landscapes to provide breeding habitat for a variety of species (Fuhlendorf et al. 2006, Toombs et al. 2010). Heterogeneity is needed at large scales $(\sim 4,000-8,000 \mathrm{ha})$ for 4 reasons: conspecific attraction may play a role in habitat selection by grassland birds (Ahlering et al. 2006), many grassland birds have minimum area requirements for nesting (Johnson and Igl 2001, Brennan and Kuvlesky 2005), some grassland birds are semi-colonial (Skagen and Yackel Adams 2010), and heterogeneity at small scales, such as within a single pasture ( 100-250 ha), may not provide sufficient patch size needs for some species (Allouche et al. 2012). On rangelands, vegetation heterogeneity is created through precipitation patterns, variable ecological sites, and disturbances such as grazing and fire (Hobbs 1996, Lipsey 2015, Scasta et al. 2015). 
Livestock grazing, the predominant use of rangelands in the United States, is a disturbance that may be managed to increase vegetation heterogeneity (Derner et al. 2009, Toombs et al. 2010, Lwiwski et al. 2015). Livestock grazing on most private grazing lands, however, is managed to increase harvest efficiency, the percent of available aboveground plant biomass consumed by a herd of grazing animals, which then increases livestock carrying capacity (Vallentine 2001, Schacht et al. 2011). Harvest efficiency is increased most commonly by improving livestock distribution of grazing through strategic placement of fence and water developments and the associated implementation of rotational grazing (Hart et al. 1993). The most common grazing systems include season-long continuous, management-intensive, and deferred-rotation (Schacht et al. 2011). Season-long continuous grazing with low to moderate stocking rates allows for greater forage selectivity by livestock, which increases the nutritional quality of forage consumed (Vallentine 2001, Vermeire et al. 2008). Management-intensive systems are characterized by implementation of management practices that minimize within-pasture differences in biotic and abiotic conditions and by rapid rotation through a relatively large number of pastures $(\geq 8) \geq 2$ times during the growing season. These practices generally reduce selective grazing, resulting in relatively even use of pasture vegetation. Deferred-rotation systems involve moving livestock through a series of pastures $(<8)$ a single time at scheduled time intervals, deferring grazing on 1 pasture until after the growing season, and changing the sequence of pasture grazing each year. One additional grazing system involves the movement of cattle through a set of pastures based on forage availability, and the pastures are used in the same order each year (i.e., fixed rotation).

Rotational systems are promoted by non-governmental organizations as beneficial for wildlife conservation (e.g., Audubon Society's bird friendly beef program; Audubon Society 2016). The federal government has also supported implementation of rotational grazing systems; most funds disbursed by the Natural Resources Conservation Service from 2004 to 2007 for conservation projects went towards improving livestock distribution through fencing and water infrastructure development (Toombs and Roberts 2009, Briske et al. 2011). Thus, there has been a shift away from season-long, continuous use of pastures to rotational grazing systems, which producers perceive as being more aligned with their production and stewardship goals (Sliwinski et al. 2018b). Sliwinski et al. (2018c), however, reported that grazing system had no effect on the variability of structure and composition of vegetation cover among grazing units, and abundance (number of individuals per ha) of 6 grassland birds did not vary among grazing systems.

Because some researchers have reported differences in vegetation structure associated with some grazing systems (Kempema 2007, Ranellucci et al. 2012), it is possible that vegetation heterogeneity across a landscape managed with multiple grazing systems would be greater than that on a landscape managed under a single grazing system. Other scientists have contended that the implementation of rotational grazing systems across the Great Plains in the United States has been a contributor to declining bird populations (Fuhlendorf and Engle 2001, Toombs et al. 2010, Fuhlendorf et al. 2012). Previous researchers have proposed that this type of management leads to structurally homogenous rangelands that do not support the full suite of grassland bird species (Toombs et al. 2010, Becerra et al. 2013). Unfortunately, there has been little research examining community structure of grassland birds and vegetation heterogeneity on landscapes that are managed by private ranching operations where there are a variety of grazing systems used. Although approaches to increase heterogeneity of vegetation structure and composition on grazing lands by combining grazing and prescribed fire (e.g., patchburn grazing) have received considerable attention from conservationists (Fuhlendorf et al. 2006, 2012), only a minor portion of grazing lands are burned in the United States. Evaluating bird abundance and composition on a wide range of grazing systems in the absence of fire is relevant.

Our goal was to examine how a variety of grazing systems used on privately managed pastures across a landscape contributed to songbird diversity, similarity of songbird communities, and vegetation heterogeneity. To that end, we had 3 objectives: assess the relationship between vegetation and songbird diversity at the management unit scale, compare structure and similarity of songbird communities across landscapes, and assess heterogeneity of vegetation in simulated landscapes to evaluate the role of grazing systems in landscape-level heterogeneity. We hypothesized that songbird diversity would respond to grazing management, and that bird communities would be different on areas managed with different grazing systems. For the third objective, we hypothesized that as more grazing systems were added to the simulated landscape, variation in vegetation structure across the landscape would increase.

\section{STUDY AREA}

We conducted this study in Cherry County, Nebraska, USA, in the Nebraska Sandhills, which is the largest contiguous grassland in North America, in 2014-2015. The Sandhills cover $50,000 \mathrm{~km}^{2}$ of rolling, grass-covered sand dunes with intermittent subirrigated meadows and wetlands. Over $94 \%$ of the area was privately owned and used primarily for beef production (Bleed and Flowerday 1998, Reece et al. 2008). Public land included 2 large tracts of land ( 40,000 ha each) managed by the United States Forest Service for multiple uses, which included cattle grazing. The soils of the uplands were fine sands mostly in the Valentine and Valentine-Els series (mixed, mesic Typic Ustipsamments). A mixture of short- and tall-grass prairie species, sand tolerant species, and species associated with permanent and ephemeral wetlands and lakes composed the vegetation in the Sandhills (Potvin and Harrison 1984). The uplands we sampled were dominated by warmseason tallgrasses including prairie sandreed (Calamovilfa longifolia), sand bluestem (Andropogon hallii), little bluestem 
(Schizachyrium scoparium), and switchgrass (Panicum virgatum), although cool-season grasses needle-and-thread (Hesperostipa comata) and prairie junegrass (Koeleria macrantha) were common. Numerous species of forbs were present, and small shrub species included leadplant (Amorpha canescens), and rose (Rosa arkansana); pockets of American plum (Prunus americana) contributed to shrub diversity (Bragg and Steuter 1996). Trees were relatively uncommon, but eastern redcedar (Juniperus virginiana) and eastern cottonwood (Populus deltoides) were abundant in localized areas away from our upland plots. In addition to songbirds, the study area's avian community in the breeding season included sharp-tailed grouse (Tympanuchus phasianellus), greater prairie-chicken (Tympanuchus cupido), mallard (Anas platyrhynchos), blue-winged teal (A. discors), trumpeter swan (Cygnus buccinator), northern harrier (Circus budsonius), and red-tailed hawk (Buteo jamaicensis). Common mammals present included mule deer (Odocoileus hemionus), white-tailed deer (O. virginianus), coyotes (Canas latrans), Ord's kangaroo rats (Dipodomys ordii), and American badgers (Taxidea taxus). Topography and elevation (Samuel R. McKelvie National Forest $=\sim 900 \mathrm{~m}$ ) were similar across the study site. Climate was typical of a mid-continental prairie region with cold winters (Dec-Feb) and hot summers (Jun-Aug). January temperatures averaged $-6.9^{\circ} \mathrm{C}$ and July temperatures averaged $23.7^{\circ} \mathrm{C}$ at the nearest weather station in Valentine, Nebraska. The longterm average annual precipitation was $533 \mathrm{~mm}$ with $542 \mathrm{~mm}$ in 2014 and $685 \mathrm{~mm}$ in 2015; approximately 76\% of the annual precipitation occurred between April and September (High Plains Regional Climate Center 2015).

We sampled 5 grazing systems (season-long continuous, management-intensive grazing, deferred rotation, fixed rotation, and dormant-season grazing) on 11 management units, where a management unit was $\geq 1$ pastures grazed by a single herd of cattle in a given year. Six management units were on private ranches and 5 management units were in the Samuel R. McKelvie National Forest. Because we conducted this study on private land and public land leased to private producers, it was not possible to experimentally manipulate the grazing systems or any other variables of interest. The predominant ecological sites on upland pastures were sands (i.e., comprised of grass-covered, rolling dunes), choppy sands (i.e., steep slopes and lower plant density), and sandy (i.e., level areas between dunes with higher plant density). Active or recovering blowouts (an area of moving sand and limited vegetation) were scattered throughout the uplands but accounted for $<1 \%$ of the sites we sampled. The number of pastures in a management unit ranged from 1 to 20 , and pasture size ranged from 94 ha to 934 ha $(\bar{x}=345 \pm 234[\mathrm{SD}]$ ha $)$.

\section{METHODS}

We collected data during the growing seasons of 2014 and 2015. Each of the 11 management units had 24 plots laid out in a grid across $\geq 1$ pastures (264 sampling plots). We evenly divided sampling points among the pastures on each management unit when possible, but on 2 units the small size of some pastures prevented this. We placed sampling plots $\geq 250 \mathrm{~m}$ apart, and $\geq 250 \mathrm{~m}$ from roads or other cover types (e.g., wet meadows, hayland). Each plot contained a point count location for birds in the center and 8 vegetation sampling points. To reduce bias from topography and ecological sites among management units, we sampled only from uplands in a landscape with relatively few lakes and wetlands and similar ecological sites.

To measure songbird relative abundance and diversity, we conducted $150-\mathrm{m}$ fixed-radius $(7.01 \mathrm{ha})$ point counts 3 times at each plot in each year (6 visits to each plot). We conducted point counts from 4 June through 3 July 2014 and 29 May through 30 June 2015 . All points were visited by $\geq 4$ different observers over the course of the study to limit observer bias. We conducted counts from 10 minutes before sunrise until about 1000 on days with no rain or site-obscuring fog, and winds $<16 \mathrm{~km} /$ hour (Hutto et al. 1986). At each point, an observer recorded all birds seen or heard for 6 minutes and the estimated distance from the observer to the bird. Observers practiced estimating distances before data collection began with pin flags at known distances and range finders. We recorded the species, sex, and behavior (observed singing, observed calling, heard singing, heard calling, observed only) of the bird (Sliwinski et al. 2018c). The University of NebraskaLincoln's Animal Care and Use Committee exempted our survey-only project on 5 February 2014.

We measured vegetation structure on all plots in May of both years because we assumed the birds we sampled in late May to early July had established territories based on the vegetation structure available in May. We collected vegetation samples in $100-\mathrm{cm} \times 50-\mathrm{cm}$ frames at 8 locations in each plot, corresponding to the point used for bird surveys: 4 samples were located at $50 \mathrm{~m}$ and 4 samples were located at $100 \mathrm{~m}$ from the plot center in each cardinal direction. By sampling multiple frames per plot, we could assess patchscale heterogeneity, defined as within $100 \mathrm{~m}$ of our sample point (the area most heavily sampled for birds), in addition to pasture and management unit scales. Our sampling design resembled the approach used by Buxton and Benson (2016), who modified the forest sampling method of Martin et al. (1997) for grassland systems. We measured litter depth to the nearest centimeter at the center of each frame; litter included dead vegetation that was lying at or below a $45^{\circ}$ angle to the ground. We measured visual obstruction readings (VOR) at each frame using a modified Robel pole (increments of $2.5 \mathrm{~cm}$ ) from 4 directions at a distance of $4 \mathrm{~m}$ and height of $1 \mathrm{~m}$ (Robel et al. 1970). We visually estimated canopy cover of litter, bare ground, live grass, standing dead vegetation, and shrubs within each frame using the following increments: $0 \%,>0$ to $<1 \%, 1-5 \%, 6-25 \%, 26-50 \%$, $51-75 \%, 76-95 \%$, and $>95 \%$. We used midpoints of the cover classes for analysis (Daubenmire 1959, Coulloudon et al. 1999, Towne et al. 2005). Means and standard deviations of each vegetation structure variable were calculated across all plots $(n=2,112)$. We summarized vegetation heterogeneity by calculating standard deviations of vegetation structure measures within each plot $(n=8)$ and then averaging those across plots $(n=264)$. 
We also collected information from the landowners about their grazing management. We requested grazing dates for each pasture that we sampled, herd numbers, and approximate animal weights. Although we were unable to confirm the information provided, many of the landowners had a history of collaborating with University of NebraskaLincoln and industry projects and understood the importance of providing accurate information. For the public management units, we requested the grazing schedules from the United States Forest Service district responsible for grazing management (Bessey Ranger District, Halsey, NE). From these sources of information, we calculated stocking rates, seasons of use, and categorized each management unit into a grazing system.

\section{Diversity Analysis}

We calculated songbird richness, Simpson diversity, and Shannon diversity for each sample plot using package picante in program $\mathrm{R}$ ( $\mathrm{R}$ version 3.4.0, www.r-project.org, accessed 23 Apr 2017). As common metrics of community diversity, species richness quantifies the number of species present, whereas the diversity indices represent 2 approaches to assessing the relative variability in abundance among species in the community. To assess the relationship of songbird diversity to management, we used linear mixed-effects models in package lmer (Bates et al. 2015). We considered several fixed effects. We included 4 stocking rate variables: stocking rate for the previous year, previous cool season (15 Apr31 May), previous warm season (1 Jun-15 Oct), and previous dormant season (15 Oct-15 Apr). We also considered a categorical stocking rate based on recommended Sandhills stocking rates where high was $>0.35 \mathrm{AUM} / \mathrm{ha}$ and low was $<0.35 \mathrm{AUM} / \mathrm{ha}$ (Kempema 2007, Sliwinski et al. 2018c). We considered a categorical fixed effect management intensity variable that reflected the relative amount of fencing, water development, and labor required for an increasing number of pastures within a grazing unit; low intensity grazing systems had $<3$ pastures, moderate intensity grazing systems had 3-6 pastures, and high intensity grazing systems had $>6$ pastures. We also included a disturbance intensity variable, which reflected a combination of categorical stocking rate and categorical management intensity. Finally, additional fixed effects included grazing system, season of use, and ownership (public or private).

We used model comparison methods (Burnham and Anderson 2002) to evaluate the relative ability of the following models to explain variation in songbird richness, Simpson diversity, and Shannon diversity: 1) grazing system, 2) season of use, 3) the 3 seasonal stocking rates, 4) stocking rate for previous year, 5) previous cool-season stocking rate, 6) previous warm-season stocking rate, 7) previous dormant-season stocking rate, 8) previous year's total stocking rate + season of use, 9) previous year's total stocking rate + grazing system, 10) a categorical variable for previous year's stocking rate, 11) a categorical variable for management intensity, 12) disturbance intensity, 13) ownership, and 14) null. We included random effects of year, management unit, and pasture in each model.

\section{Community Analysis}

We used a multivariate approach to examine differences in songbird communities across grazing systems, management units, categorical stocking rates, categorical management intensities, and vegetation structure measures because this approach included species composition and relative abundance. Because pasture was the scale at which management occurred, we assessed songbird communities at the level of the pasture, but we grouped pastures according to the grazing system. We used all 28 songbird species in the community analysis (Table 1). We accounted for the different sampling effort in some pastures by dividing the number of detections in a pasture by the number of plots in that pasture. We calculated the Bray-Curtis dissimilarity on the square-root transformed species relative abundance data (Borcard et al. 2011) across all pastures and years using package vegan in program $\mathrm{R}$. We then used this metric to assess community similarity across grazing systems using a non-metric multidimensional scaling (NMDS) analysis (Minchin 1987) using the metaMDS function in package vegan in program $R$. We then fit the vegetation structure measures to the resulting NMDS to examine the relationships of the bird community to vegetation structure features (envfit function in package vegan).

Table 1. All songbird detections in the Nebraska Sandhills, USA, 20142015.

\begin{tabular}{|c|c|c|}
\hline Species & Scientific name & $\begin{array}{c}\text { Total } \\
\text { detections }\end{array}$ \\
\hline Grasshopper sparrow & $\begin{array}{l}\text { Ammodramus } \\
\text { savannarum }\end{array}$ & 2,606 \\
\hline Western meadowlark & Sturnella neglecta & 1,859 \\
\hline Brown-headed cowbird & Molotbrus ater & 1,068 \\
\hline Horned lark & Eremophila alpestris & 1,028 \\
\hline Lark sparrow & Chondestes grammacus & 1,010 \\
\hline Dickcissel & Spiza americana & 437 \\
\hline Field sparrow & $\stackrel{1}{\text { Spizella pusilla }}$ & 327 \\
\hline Red-winged blackbird & Agelaius phoeniceus & 224 \\
\hline Mourning dove & Zenaida macroura & 110 \\
\hline Blue grosbeak & Passerina caerulea & 88 \\
\hline Vesper sparrow & Pooecetes gramineus & 58 \\
\hline Bell's vireo & Vireo bellii & 44 \\
\hline American goldfinch & Spinus tristis & 27 \\
\hline Orchard oriole & Icterus spurius & 23 \\
\hline Spotted towhee & Pipilo maculatus & 22 \\
\hline Brown thrasher & Toxostoma rufum & 20 \\
\hline Eastern kingbird & Tyrannus tyrannus & 17 \\
\hline $\begin{array}{l}\text { Yellow-headed } \\
\text { blackbird }\end{array}$ & $\begin{array}{l}\text { Xanthocephalus } \\
\text { xanthocephalus }\end{array}$ & 14 \\
\hline Common grackle $\mathrm{e}^{\mathrm{a}, \mathrm{b}}$ & Quiscalus quiscula & 6 \\
\hline $\begin{array}{l}\text { Common } \\
\text { yellowthroat }^{\mathrm{a}, \mathrm{b}}\end{array}$ & Geothlypis trichas & 5 \\
\hline Cassin's sparrow ${ }^{\mathrm{b}}$ & Peucaea cassinii & 4 \\
\hline Western kingbird ${ }^{\mathrm{b}}$ & Tyrannus verticalis & 4 \\
\hline Eastern towhee $^{\mathrm{a}}$ & Pipilo erythrophthalmus & 3 \\
\hline Lark bunting ${ }^{\mathrm{a}, \mathrm{b}}$ & Calamospiza melanocorys & 3 \\
\hline Barn swallow ${ }^{b}$ & Hirundo rustica & 2 \\
\hline Tree swallow ${ }^{b}$ & Tachycineta bicolor & 1 \\
\hline Bobolink $^{\mathrm{b}}$ & Dolichonyx oryzivorus & 1 \\
\hline Loggerhead shrike ${ }^{b}$ & Lanius ludovicianus & 1 \\
\hline
\end{tabular}

${ }^{\text {a }}$ Rare species ( $<10$ detections) found on public land.

${ }^{\mathrm{b}}$ Rare species ( $<10$ detections) found on private land. 
We used a multi-response permutation procedure (Mielke et al. 1976) using the mrpp function in package vegan to evaluate the relationship between management and variation in the songbird communities. We assessed the role of management unit, stocking rate (high or low), ownership (public or private), management intensity (high, moderate, or low), and grazing system. Each of these factors had the potential to affect vegetation composition and structure, and we used this analysis to determine if variation in management (ownership and grazing decisions) ultimately caused variation in the songbird community. The chance-corrected within-group agreement value $(A)$ indicates variation that is explained by a grouping factor in the MRPP and is comparable to a coefficient of determination in linear regression (Oksanen et al. 2016). We used $A$ and the significance value to interpret overlap of communities.

\section{Landscape Analysis}

We selected our field study sites to include a variety of grazing systems in proximate ranches, but logistics prevented us from establishing an experimental landscape with a balanced distribution of grazing systems. Thus, to leverage our field data to examine our hypothesis that more grazing systems on a landscape would create greater structural vegetation heterogeneity, we used the empirical data in a simulation analysis. We created artificial landscapes to assess large-scale heterogeneity by incorporating 1 to 3 different grazing systems from $\geq 2$ management units. In each simulation, we selected from 3 types of grazing systems: management intensive grazing (MIG; $n=2)$, deferred rotation $(\mathrm{DR} ; n=5)$, and season-long, continuous $(\mathrm{C} ; n=2)$ to create 7 types of landscapes, defined by the grazing systems present: MIG-MIG, DR-DR, C-C, MIG-DR, MIG-C, DR-C, and MIG-DR-C. For example, a MIG-MIG landscape would include data from 2 ranches, both using the management intensive grazing system, whereas a DR-C landscape would have data from 2 ranches, 1 using a deferred rotation and 1 using a continuous system. We did not include dormant season and fixed-rotation systems in our simulations because each type was represented by only 1 grazing unit. For each landscape combination, we simulated 1,000 artificial landscapes of a given combination. During each simulation of a landscape, we randomly selected the 2 or 3 management units from which the empirical data should be drawn based on the grazing systems in the landscape being created, then randomly selected half (in the case of 2 management units) or a third (in the case of 3 management units) of the vegetation structure samples from the empirical raw data for each management unit. Thus, we created a landscape with the same sample size as 1 whole management unit in this study (i.e., 192 samples). The output of each of the 1,000 simulations for each landscape type was the standard deviation of VOR, litter depth, and bare ground to represent the level of heterogeneity inherent in the entire artificial landscape. We selected the 3 structural components because of their relevance to rangeland managers and wildlife. We conducted simulations in $\mathrm{R}$ version 3.4, and we created 95\% confidence intervals and boxplots to assess the evidence available to support our hypothesized relationship among the different landscapes.

\section{RESULTS}

Managers used 5 different grazing systems on the 11 management units selected for this study: season-long continuous grazing, deferred rotation grazing, management intensive grazing, dormant-season grazing, and a fixed rotation system. Each grazing system was represented on public and private land except for the dormant-season and fixed rotation systems (private land only). The stocking rate was typically lower on public land than on private land; the mean stocking rates in 2014 and 2015 across the 5 public management units and 6 private management units were $0.52 \mathrm{AUM} / \mathrm{ha}$ and $0.98 \mathrm{AUM} / \mathrm{ha}$, respectively.

Vegetation characteristics did not change appreciably across the study sites between 2014 and 2015 although VOR and mean litter depth were $20 \%$ and $30 \%$ less in 2015 than in 2014, respectively, and mean bare ground was $46 \%$ greater in 2015 than 2014 (Table 2). Local-scale vegetation heterogeneity was similar for all measures in 2014 and 2015 except for litter depth, which had higher heterogeneity in 2014 than 2015 (Table 3).

\section{Songbird Diversity}

Songbird richness ranged from 2-10 species/plot; $53 \%$ of plots had 5 or 6 songbird species. Shannon diversity ranged from 0.41-2.2, and Simpson's diversity ranged from 0.24-0.88. Each of the diversity measures was best explained by the previous dormant season's stocking rate (Shannon diversity AIC weight $\left[w_{i}\right]=0.72$, Simpson diversity $w_{i}=0.53$, richness $w_{i}=0.79$; Tables S1-S3). Each of the diversity measures decreased as dormant-season stocking rate increased, although the effect was small (Fig. 1). Richness declined by about 0.5 species/plot with an increase in $0.5 \mathrm{AUM} / \mathrm{ha}$.

\section{Songbird Community}

We detected 28 songbird species in 2014 and 2015 (Table 1). The 5 most common species were grasshopper sparrow, western meadowlark (Sturnella neglecta), brownheaded cowbird (Molothrus ater), horned lark, and lark sparrow (Chondestes grammacus). The 5 most common avian species made up $84 \%$ of observations.

The community NMDS analysis, with stress of 0.183 indicating a good fit (Clarke and Warwick 2001), revealed overlap in bird communities among the different grazing

Table 2. Mean vegetation structure measures across 11 sites in the Nebraska Sandhills, USA, 2014-2015 ( $n=2,112$ sample frames).

\begin{tabular}{lrrrrr}
\hline & \multicolumn{2}{c}{$\mathbf{2 0 1 4}$} & & \multicolumn{2}{c}{$\mathbf{2 0 1 5}$} \\
\cline { 2 - 3 } \cline { 6 - 7 } & \multicolumn{1}{c}{$\bar{x}$} & SD & & \multicolumn{1}{c}{$\boldsymbol{x}$} & SD \\
\hline Visual obstruction reading (cm) & 4.87 & 5.60 & & 3.87 & 5.42 \\
Litter depth (cm) & 3.31 & 3.53 & & 2.26 & 2.42 \\
Litter cover (\%) & 25.91 & 20.40 & & 34.58 & 28.36 \\
Standing dead vegetation cover (\%) & 11.94 & 11.60 & & 13.12 & 14.48 \\
Grass cover (\%) & 22.76 & 19.60 & & 22.60 & 19.42 \\
Bare ground (\%) & 38.81 & 27.45 & & 56.80 & 27.90 \\
Shrub cover (\%) & 6.46 & 12.83 & & 3.74 & 9.34 \\
\hline
\end{tabular}


Table 3. Heterogeneity of vegetation structure measures across 11 sites in the Nebraska Sandhills, USA, 2014-2015. Values shown are for plotspecific standard deviations ( $n=264$ plots).

\begin{tabular}{lrrrrr}
\hline & \multicolumn{2}{c}{$\mathbf{2 0 1 4}$} & & \multicolumn{2}{c}{$\mathbf{2 0 1 5}$} \\
\cline { 2 - 3 } \cline { 6 - 7 } & \multicolumn{1}{c}{$\bar{x}$} & SD & & $\bar{x}$ & SD \\
\hline Visual obstruction reading (cm) & 3.68 & 3.45 & & 3.50 & 3.79 \\
Litter depth (cm) & 2.75 & 1.72 & & 1.90 & 1.14 \\
Litter cover (\%) & 16.40 & 7.32 & & 19.91 & 7.80 \\
Standing dead vegetation cover (\%) & 8.59 & 5.44 & & 11.06 & 6.25 \\
Grass cover (\%) & 14.09 & 7.77 & & 16.12 & 6.71 \\
Bare ground (\%) & 19.83 & 7.77 & & 24.46 & 6.78 \\
\hline
\end{tabular}

systems (Fig. 2). The most common birds (i.e., grasshopper sparrow, western meadowlark, and lark sparrow) were at the center of the hulls outlining each grazing system in the NMDS plot, indicating that they were detected in each
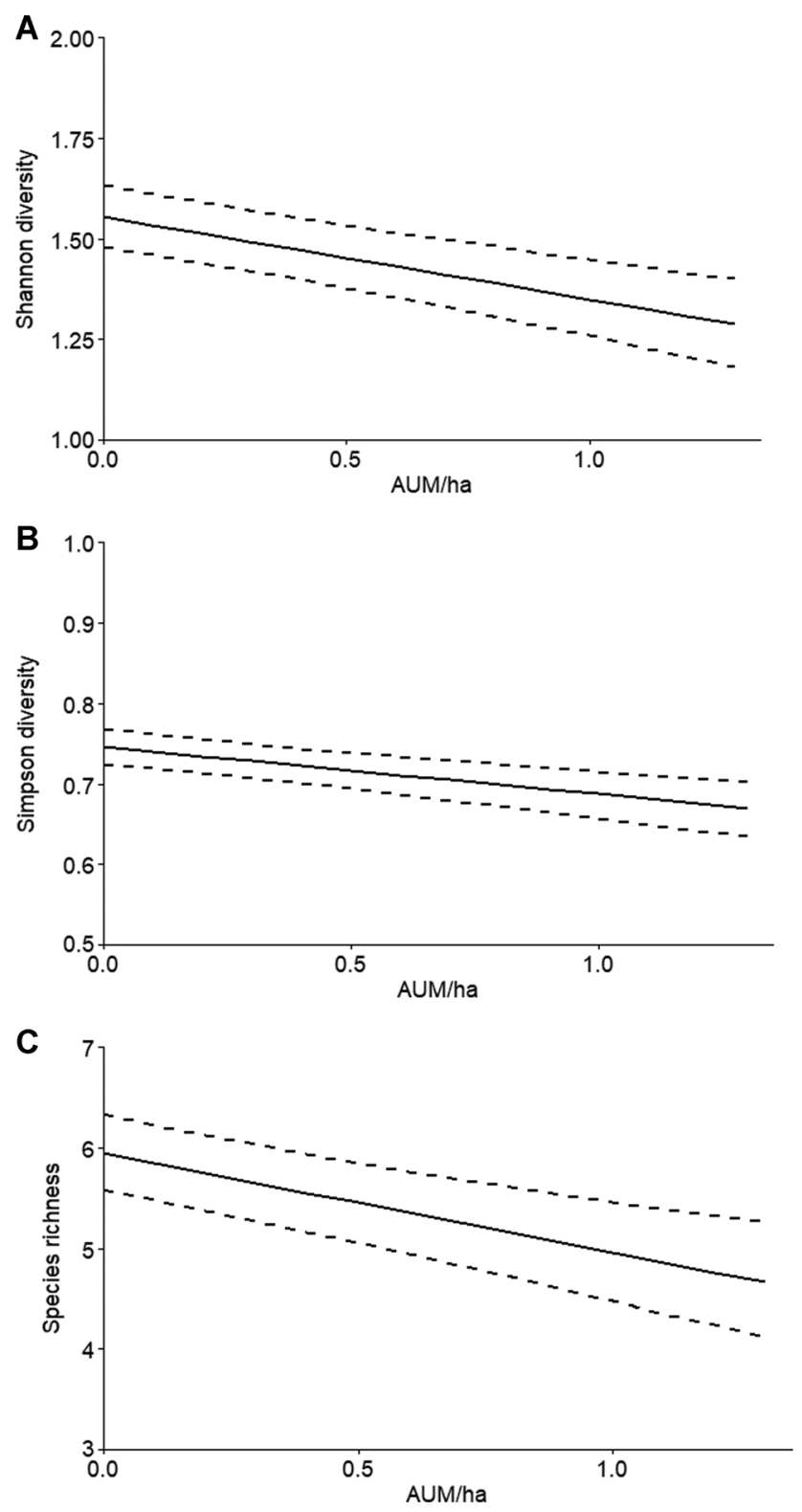

Figure 1. Model-predicted relationships of Shannon diversity (A), Simpson diversity (B), and species richness (species/7.01 ha; C) for birds to dormant-season stocking rates in the Nebraska Sandhills, USA, 2014-2015. AUM = animal unit months. grazing system. Songbirds were related to vegetation measures as expected based on their habitat preferences (Fig. 3). Many species, such as dickcissel (Spiza americana) and Bell's vireo (Vireo bellii), were more commonly in areas with greater vegetation cover and structure, but vesper sparrow (Pooecetes gramineus), orchard oriole (Icterus spurius), and lark sparrow were associated with bare ground and less vegetation cover. Each of the 5 variables we explored were significantly related to the structure of the songbird community according to the multi-response permutation procedure, but the effect sizes $(A)$ were small for most (Table 4). The variable explaining the most variation in bird communities was the management unit (i.e., individual ranch or grazing allotment, $A=0.252)$. We found rare species $(<10$ detections) on both public and private land (Table 1). Grazing system explained little of the bird community structure $(A=0.081)$ but more than stocking rate $(A=0.016)$ or management intensity $(A=0.051)$.

\section{Analysis of Simulated Landscapes}

When simulated landscapes included a diversity of grazing systems, we did not observe greater heterogeneity in any measures of vegetation structure. The mean heterogeneity (SD) of bare ground ranged from $28-29 \%$ across the 7 types of simulated landscapes with data from 2014 and 27-29\% with data from 2015 (Fig. 4). The highest mean level of heterogeneity of bare ground using data from 2014 was on the simulated landscape that included 2 management units each with deferred rotation grazing (Fig. 4; DR-DR); the deferred rotation type of landscape also had the greatest range in variability in bare ground in our simulations. Our data from 2015 resulted in virtual landscapes from which the highest mean level of heterogeneity was the type that included 2 units of management intensive grazing (Fig. 4; MIG-MIG). The greatest range in variability in bare ground, using data from 2015, was a landscape with 2 management units each with season-long, continuous grazing (C-C). The mean level of heterogeneity across the 7 types of landscapes was quite similar with regard to litter depth using data from 2014 and 2015 with the exception of the MIG-MIG landscape, which had markedly low heterogeneity of litter depth compared to the rest of the simulated landscape types (Fig. 5). The opposite was true for VOR; the MIG-MIG type of simulated landscape had the highest level of heterogeneity in VOR (Fig. 6).

\section{DISCUSSION}

Although we detected a response of songbird diversity to stocking rate (AUM/ha), our hypothesis that bird communities would vary by grazing system was not supported. Further, our simulations demonstrated that a diversity of grazing systems in a landscape does not result in a higher level of large-scale heterogeneity of vegetation structure across the landscape. We were unable to identify a grazing system or set of grazing systems that consistently resulted in greater simulated landscape heterogeneity during both years and across the 3 tested habitat variables (i.e., SD bare ground, SD litter depth, or SD VOR), which follows results 


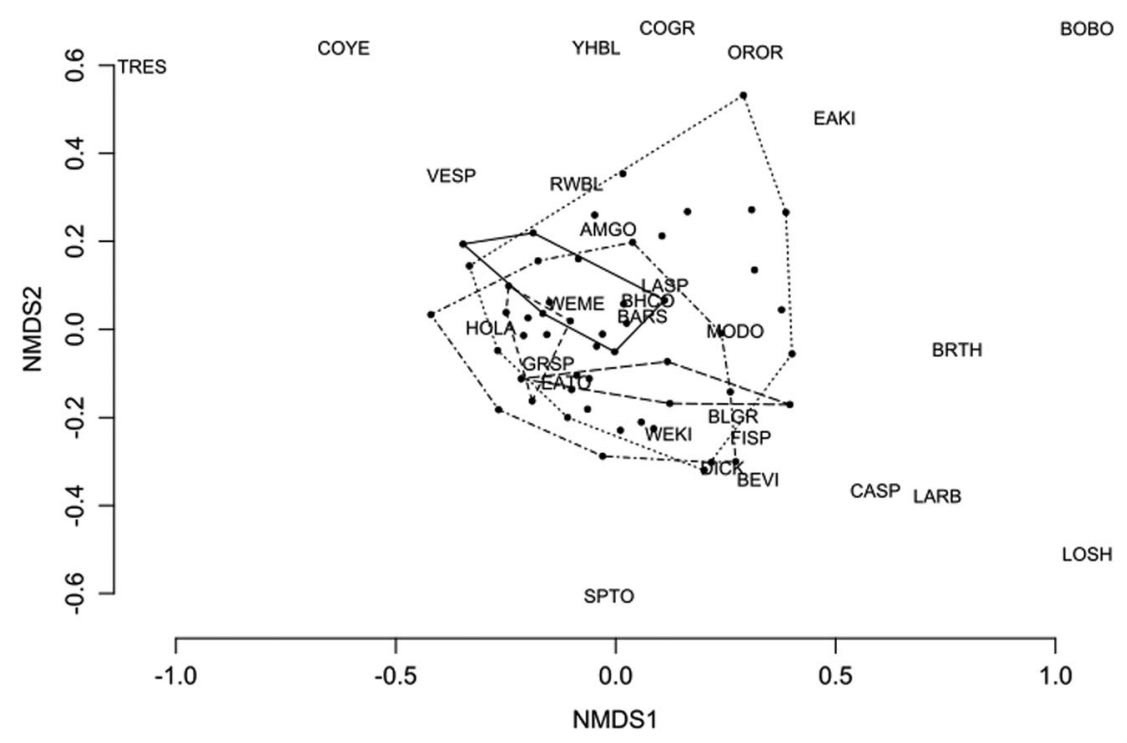

Figure 2. Non-metric multidimensional scaling (NMDS) plot of NMDS1 and NMDS2 scores for all songbirds detected in the Nebraska Sandhills, USA, 2014-2015. Hulls are around the perimeter of each grazing system (solid line $=$ season-long continuous, dashed line $=$ dormant-season, dotted line $=$ deferred rotation, dot-dash line $=$ management intensive, long-dash line $=$ fixed rotation). Points are pastures and are plotted such that pastures with more similar bird communities are closer in space; bird species in a given area of the plot indicate greater relative abundance of that species in that region of the plot and preference for similar habitat features. Bird abbreviations: AMGO (American goldfinch), BARS (barn swallow), BEVI (Bell's vireo), BLGR (blue grosbeak), BOBO (bobolink), BRTH (brown thrasher), BHCO (brown-headed cowbird), CASP (Cassin's sparrow), COGR (common grackle), COYE (common yellowthroat), DICK (dickcissel), EAKI (eastern kingbird), EATO (eastern towhee), FISP (field sparrow), GRSP (grasshopper sparrow), HOLA (horned lark), LARB (lark bunting), LASP (lark sparrow), LOSH (loggerhead shrike), MODO (mourning dove), OROR (orchard oriole), RWBL (red-winged blackbird), SPTO (spotted towhee), TRES (tree swallow), VESP (vesper sparrow), WEKI (western kingbird), WEME (western meadowlark), and YHBL (yellow-headed blackbird).

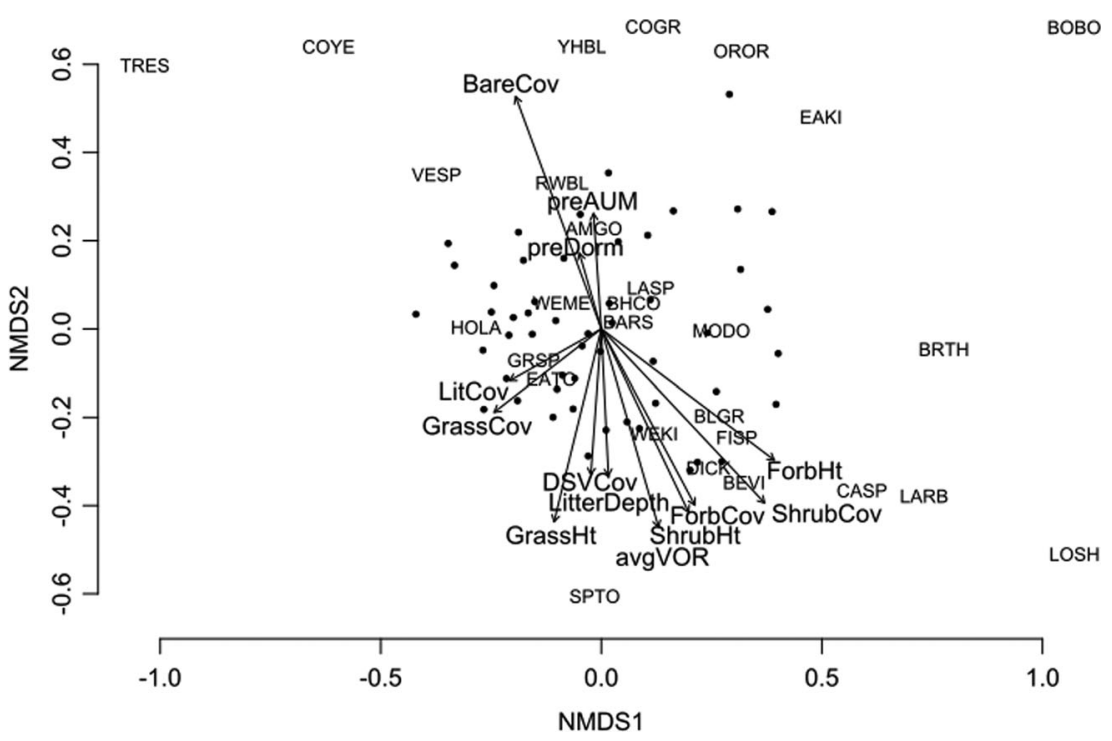

Figure 3. Non-metric multidimensional scaling (NMDS) plot of NMDS1 and NMDS2 scores for all songbirds detected in the Nebraska Sandhills, USA, 2014-2015, overlaid with vegetation structure variables. Points are pastures and are plotted such that pastures with more similar bird communities are closer in space; bird species in a given area of the plot indicate greater relative abundance of that species in that region of the plot. Arrows point in the direction of increasing vegetation measures. Bird abbreviations: AMGO (American goldfinch), BARS (barn swallow), BEVI (Bell's vireo), BLGR (blue grosbeak), BOBO (bobolink), BRTH (brown thrasher), BHCO (brown-headed cowbird), CASP (Cassin's sparrow), COGR (common grackle), COYE (common yellowthroat), DICK (dickcissel), EAKI (eastern kingbird), EATO (eastern towhee), FISP (field sparrow), GRSP (grasshopper sparrow), HOLA (horned lark), LARB (lark bunting), LASP (lark sparrow), LOSH (loggerhead shrike), MODO (mourning dove), OROR (orchard oriole), RWBL (red-winged blackbird), SPTO (spotted towhee), TRES (tree swallow), VESP (vesper sparrow), WEKI (western kingbird), WEME (western meadowlark), and YHBL (yellow-headed blackbird). Habitat abbreviations: BareCov (bare ground), preAUM (previous year's stocking rate), preDorm (previous dormant season's stocking rate), LitCov (litter cover), GrassCov (grass cover), GrassHt (grass height), LitDepth (litter depth), DSVCov (standing dead vegetation cover), avgVOR (mean visual obstruction reading), ShrubHt (mean shrub height), ForbCov (forb cover), ShrubCov (shrub cover), and ForbHt (forb height). 
Table 4. Multi-response permutation procedure results for the relationship between 5 different management variables and variation in the songbird communities in the Nebraska Sandhills, USA, 2014-2015. The chance-corrected within-group agreement value $(A)$ indicates variation that is explained by each grouping factor.

\begin{tabular}{lcc}
\hline Grouping variable & Significance of test & $\boldsymbol{A}$ \\
\hline Management unit & 0.001 & 0.252 \\
Grazing system & 0.001 & 0.081 \\
Management intensity (high, & 0.002 & 0.051 \\
$\quad$ moderate, low) & & \\
Ownership (public or private) & 0.001 & 0.049 \\
Stocking rate (high, low) & 0.033 & 0.016 \\
\hline
\end{tabular}
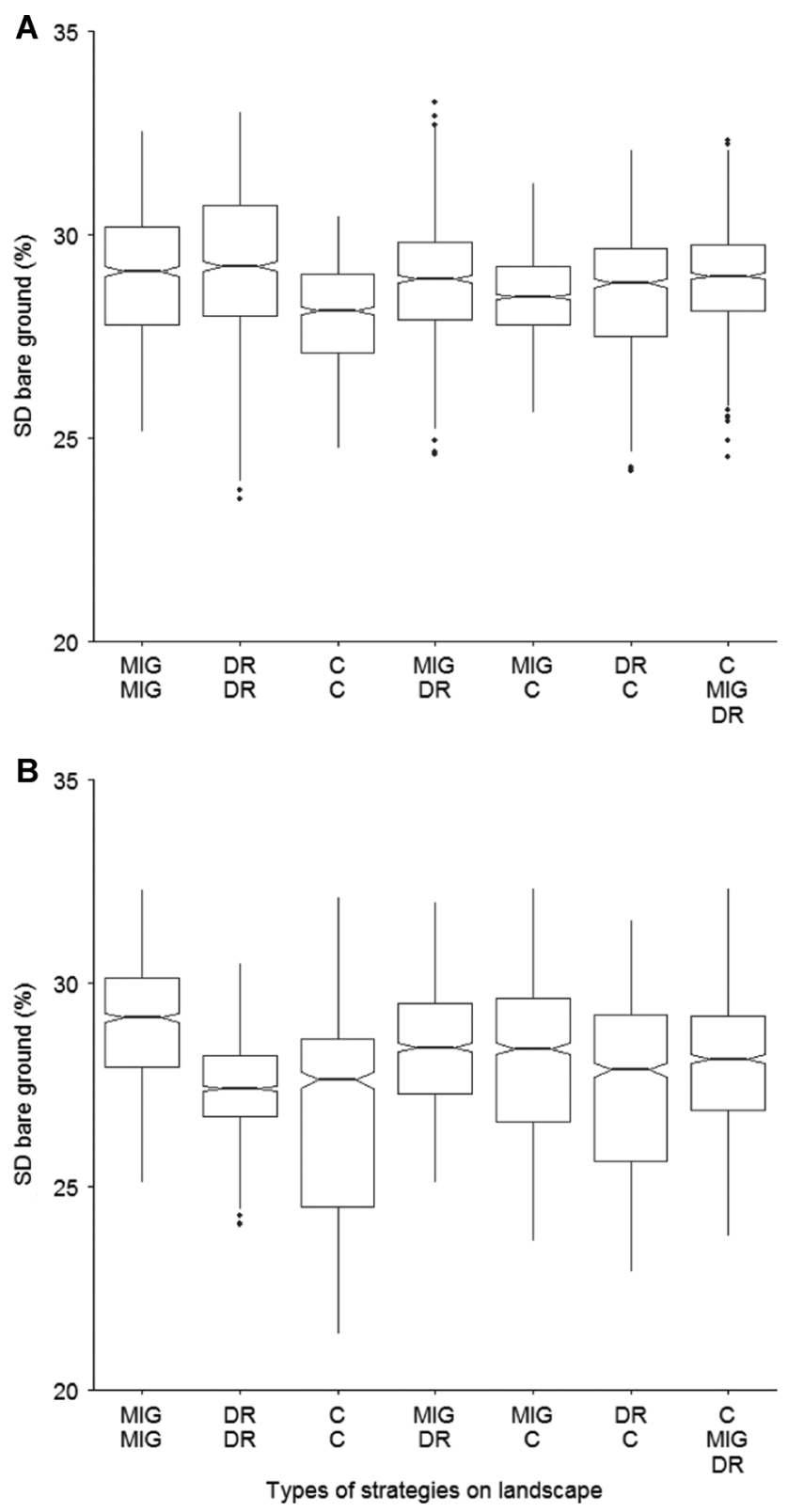

Figure 4. Mean heterogeneity (SD) in bare ground (\%) on landscapes with various combinations of grazing systems in 2014 (A) and 2015 (B). Notches indicate $95 \%$ confidence interval; boxes indicate first and third quartiles. We simulated landscapes using random samples of empirical data from the Nebraska Sandhills, USA, 2014-2015 $(n=7,000)$. Abbreviations: MIG (management intensive grazing), DR (deferred rotation), and C (continuous, season-long).
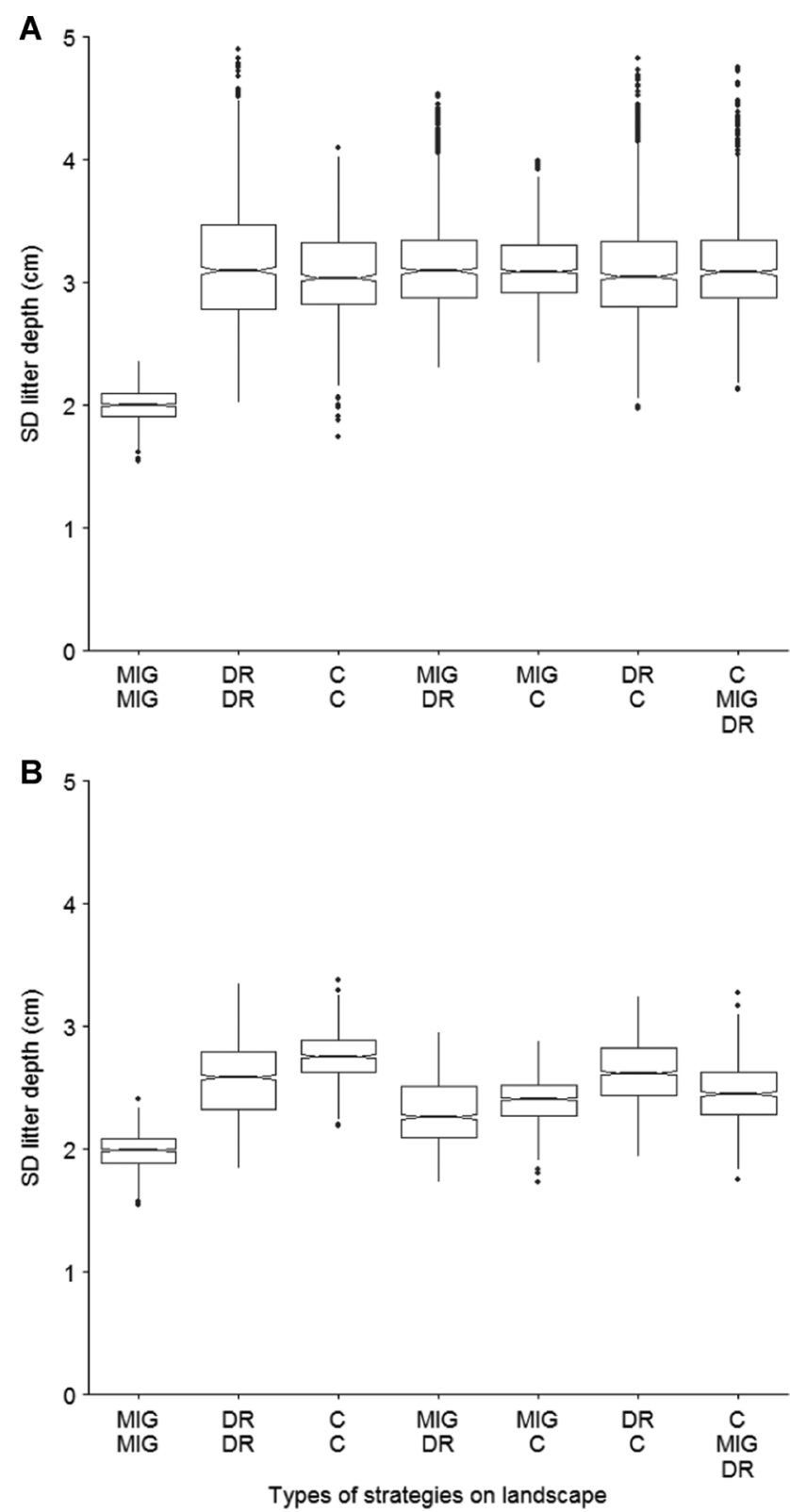

Figure 5. Mean heterogeneity (SD) in litter depth $(\mathrm{cm})$ on landscapes with various combinations of grazing systems in 2014 (A) and 2015 (B). Notches indicate 95\% confidence interval; boxes indicate first and third quartiles. We simulated landscapes using random samples of empirical data from the Nebraska Sandhills, USA, 2014-2015 $(n=7,000)$. Abbreviations: MIG (management intensive grazing), DR (deferred rotation), and C (continuous, season-long).

reported by Sliwinski et al. (2018c) regarding a lack of effect of grazing system on vegetation structure in a concurrent study at our study site. Further, the range of mean heterogeneity for our 3 vegetation structure measures across the 7 types of landscapes was so small that it seems unlikely to be ecologically relevant. The lack of differences in bird communities that we reported across the study area supports the lack of ecological relevance of the small differences in vegetation heterogeneity among grazing systems.

Although variation in the composition of songbird communities was significantly related to each of the variables we examined with the multi-response permutation procedure, 

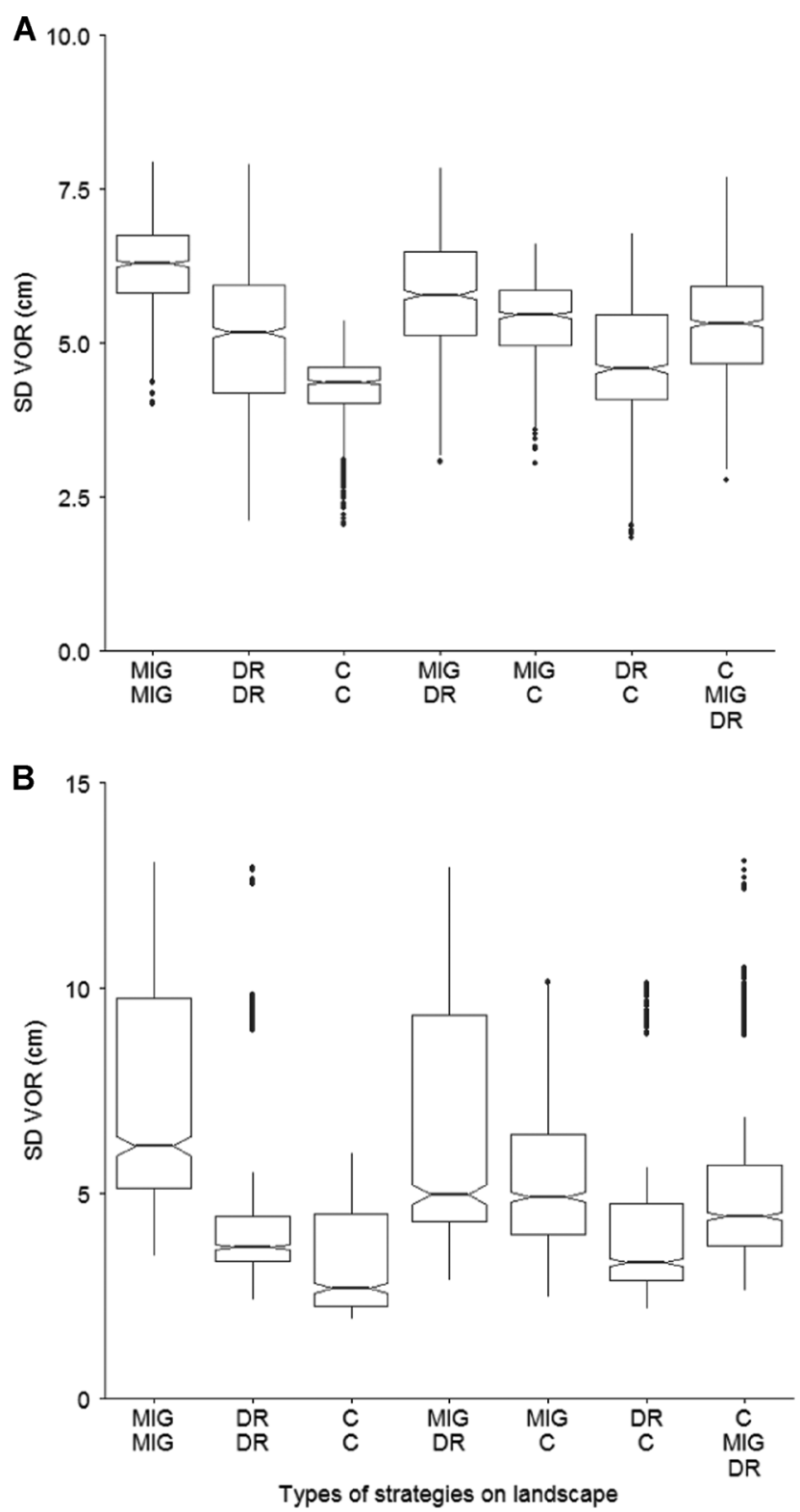

Figure 6. Mean heterogeneity (SD) in visual obstruction reading (VOR $\mathrm{cm}$ ) on landscapes with various combinations of grazing systems in 2014 (A) and 2015 (B). Notches indicate 95\% confidence interval; boxes indicate first and third quartiles. We simulated landscapes using random samples of empirical data from the Nebraska Sandhills, USA, 2014-2015 $(n=7,000)$. Abbreviations: MIG (management intensive grazing), DR (deferred rotation), and C (continuous, season-long).

effect sizes were small. Ownership of management units (i.e., private ranches or public grazing allotments) explained little of the variation in bird communities, despite the long history of differential stocking rates and seasons of use between public and private land. Thus, our assessment suggests that the conservative management on the Forest Service lands did not result in markedly different grassland bird communities. Overall differences in stocking rate related to ownership in a North Dakota, USA, study (NGO vs. public) also explained little variation in a tallgrass prairie bird community (Ahlering and Merkord 2016). Thus, current evidence does not support the importance of grazing management to songbird communities when it is couched within a narrow range of grazing intensity and excludes other environmental effects, such as fire, that can cause extremes in vegetation structure and composition. Only the management unit variable (i.e., ranch) explained a substantial amount of variation in bird communities, and Sliwinski et al. (2018c) reported similar effects of individual management units on abundance of 5 songbird species (grasshopper sparrow, lark sparrow, western meadowlark, horned lark, field sparrow [Spizella pusilla]). The differences among management units in the songbird communities were most likely not a result of grazing management but rather due to landscape features, such as the proximity to forest or wetland patches or the presence of shrubs, 2 things that were common on the units that had more orchard orioles, eastern kingbirds, and brown thrashers (Toxostoma rufum).

Our results suggest that bird communities may be homogenized by the narrow focus on beef production in the Great Plains. Although every producer manages their land slightly differently, their goals are similar: to sustain beef production through efficient use of the forage resource for livestock (Vallentine 2001, Reece et al. 2007, Sliwinski et al. 2018a). Managers use relatively similar stocking rates and manage for similar high-yielding, dominant plant species to optimize beef production, which, at least in the Nebraska Sandhills, leads to homogeneity of vegetation (Sliwinski et al. 2018c) and bird communities. Managing for the extremes in vegetation cover, from bare soil to dense plants, results in vegetation heterogeneity but lessens the suitability for efficient use of the potential forage resource by grazing cattle. As an example, bare soil is critical for some species of conservation concern, such as the mountain plover (Charadrius montanus), in the shortgrass prairie (Augustine and Derner 2012); whereas, denser grass and shrub patches are preferred by loggerhead shrikes (Lanius ludovicianus). Ranchers, however, manage against extremes in vegetation cover. Bare soil is avoided because of concerns about shortand long-term consequences on forage production. On the opposite end of the spectrum, grass is not wasted; they manage for full use of forage resources to avoid economic inefficiencies associated with low use of vegetation cover (Sliwinski et al. 2018b).

Researchers suggests that biodiversity in the Great Plains region of North America is at risk of rapid decline as a result of land use change (Newbold et al. 2016). The bird communities we sampled show evidence of this decline because they were missing or had very few of species we expected to see, such as long-billed curlews (Numenius americanus), lark buntings (Calamospiza melanocorys), and common nighthawks (Chordeiles minor); these species are the dark diversity that is missing from the community (Pärtel et al. 2011). This is not to say that land managed for beef production provides unsuitable habitat characteristics for grassland species; on the contrary, the habitat is adequate for a subset of the total possible species pool. Previous researchers have concluded that grazing management on private and public lands contributes to the homogenization of rangeland plant 
species composition and structure by improving grazing distribution and enhancing harvest efficiency (Fuhlendorf and Engle 2001, With et al. 2008, Toombs et al. 2010). Fire-grazing interactions may be needed to achieve higher levels of heterogeneity and biodiversity than exist currently in rangelands because this will provide heavily disturbed and rested landscapes (Fuhlendorf and Engle 2004, Augustine and Derner 2012, Winter et al. 2012).

\section{MANAGEMENT IMPLICATIONS}

Because the bulk of remaining native grasslands is privately owned, conservationists must work with private producers to create the full spectrum of habitat characteristics needed by wildlife if we hope to prevent continued declines of native grassland species. The use of multiple grazing systems by landowners on a landscape has been seen as an easy solution by conservation planners who assume that vegetation heterogeneity and bird diversity are enhanced with implementation of an increasing number of the full array of grazing systems on a grassland landscape. We suspect that effective tools to increase heterogeneity in grasslands will include the use of extreme stocking rates (i.e., very low and very high) and prescribed fires. Incentives will be necessary to encourage private landowners and managers to add goals for heterogeneity to their beef production goals. Further, our research suggests that the role of public and nongovernmental organization lands should be further evaluated in the context of the regional landscape to provide missing ecosystem components such as bare ground to support diverse regional communities of grassland birds.

\section{ACKNOWLEDGMENTS}

We are grateful to the producers who granted us access to their land. We thank our research technicians for assistance with data collection, and we appreciate logistical assistance from J. C. Geise and M. Nenneman. We are grateful to G. Wright, W. Vohdenal, and other personnel for permission and assistance with our work on the Samuel R. McKelvie National Forest. Funding for this work was provided from Federal Aid in Wildlife Restoration Project W-103-R through the Nebraska Game and Parks Commission.

\section{LITERATURE CITED}

Ahlering, M. A., D. H. Johnson, and J. Faaborg. 2006. Conspecific attraction in a grassland bird, the Baird's sparrow. Journal of Field Ornithology 77:365-371.

Ahlering, M. A., and C. L. Merkord. 2016. Cattle grazing and grassland birds in the northern tallgrass prairie. Journal of Wildlife Management 80:643-654.

Allouche, O., M. Kalyuzhny, G. Moreno-Rueda, M. Pizarro, and R. Kadmon. 2012. Area-heterogeneity tradeoff and the diversity of ecological communities. Proceedings of the National Academy of Sciences 109:17495-17500.

Audubon Society. 2016. Working lands, grassland birds. <http://www. audubon.org/conservation/project/grassland-birds > . Accessed 28 Nov 2016.

Augustine, D. J., and J. D. Derner. 2012. Disturbance regimes and mountain plover habitat in shortgrass steppe: large herbivore grazing does not substitute for prairie dog grazing or fire. Journal of Wildlife Management 76:721-728.

Bates, D., M. Mächler, B. M. Bolker, and S. C. Walker. 2015. Fitting linear mixed-effects models using lme4. Journal of Statistical Software $67: 1-48$.
Becerra, T. A., D. M. Engle, R. D. Elmore, and S. D. Fuhlendorf. 2013. Contrasting preference for grassland landscapes among population groups in the central and southern Great Plains. Rangeland Ecology \& Management 66:529-538.

Bleed, A. S., and C. A. Flowerday. 1998. An atlas of the Sand Hills. Third edition. World Herald Foundation, Omaha, Nebraska, USA.

Borcard, D., F. Gillet, and P. Legendre. 2011. Numerical ecology with R. First edition. Springer, New York, New York, USA.

Bragg, T. B., and A. A. Steuter. 1996. Prairie ecology: the mixed prairie. Pages 53-65 in F. Samson and F. Knopf, editors. Prairie conservation: preserving North America's most endangered ecosystem. Island Press, Washington, D.C., USA.

Brennan, L. A., and W. P. Kuvlesky, Jr. 2005. North American grassland birds: an unfolding conservation crisis? Journal of Wildlife Management 69:1-13.

Briske, D. D., N. F. Sayre, L. Huntsinger, M. E. Fernández-Giménez, B. Budd, and J. D. Derner. 2011. Origin, persistence, and resolution of the rotational grazing debate: integrating human dimensions into rangeland research. Rangeland Ecology \& Management 64:325-334.

Burnham, K. P., and D. C. Anderson. 2002. Model selection and multimodel inference: a practical information-theoretic approach. Springer, Fort Collins, Colorado, USA.

Buxton, V. L., and T. J. Benson. 2016. Conservation-priority grassland bird response to urban landcover and habitat fragmentation. Urban Ecosystems 19:599-613.

Clarke, K. R., and R. M. Warwick. 2001. Change in marine communities: an approach to statistical analysis and interpretation. Second edition. PRIMER-E, Plymouth, United Kingdom.

Coulloudon, B., K. Eshelman, J. Gianola, H. Ned, L. Hughes, C. Johnson, M. Pellant, P. Podborny, A. Rasmussen, B. Robles, et al. 1999. Sampling vegetation attributes. Technical Reference 1734-4. Bureau of Land Management and Forest Service, Denver, Colorado, USA.

Daubenmire, R. 1959. A canopy-coverage method of vegetation analysis. Northwest Science 33:43-64.

Derner, J. D., W. K. Lauenroth, P. Stapp, and D. J. Augustine. 2009. Livestock as ecosystem engineers for grassland bird habitat in western Great Plains of North America. Rangeland Ecology \& Management 62:111-118.

Fuhlendorf, S. D., and D. M. Engle. 2001. Restoring heterogeneity on rangelands: ecosystem management based on evolutionary grazing patterns. BioScience 51:625-632.

Fuhlendorf, S. D., and D. M. Engle. 2004. Application of the fire-grazing interaction to restore a shifting mosaic on tallgrass prairie. Journal of Applied Ecology 41:604-614.

Fuhlendorf, S. D., D. M. Engle, R. D. Elmore, R. F. Limb, and T. G. Bidwell. 2012. Conservation of pattern and process: developing an alternative paradigm of rangeland management. Rangeland Ecology \& Management 65:579-589.

Fuhlendorf, S. D., W. C. Harrell, D. M. Engle, R. G. Hamilton, C. A. Davis, and D. M. Leslie, Jr. 2006. Should heterogeneity be the basis for conservation? Grassland bird response to fire and grazing. Ecological Applications 16:1706-1716.

Hart, R. H., J. Bissio, M. J. Samuel, and J. W. Waggoner, Jr. 1993. Grazing systems, pasture size, and cattle grazing behavior, distribution and gains. Journal of Range Management 46:81-87.

High Plains Regional Climate Center. 2015. Climate data. http://www. hprcc.unl.edu. Accessed 8 Oct 2018.

Hobbs, N. T. 1996. Modification of ecosystems by ungulates. Journal of Wildlife Management 60:695-713.

Hutto, R. L., S. M. Pletschet, and P. Hendricks. 1986. A fixed-radius point count method for nonbreeding and breeding season use. Auk 103:593-602.

Johnson, D. H., and L. D. Igl. 2001. Area requirements of grassland birds: a regional perspective. Auk 118:24-34.

Kempema, S. 2007. The influence of grazing systems on grassland bird density, productivity, and species richness on private rangeland in the Nebraska Sandhills. Thesis, University of Nebraska, Lincoln, USA.

Lipsey, M. 2015. Cows and plows: science-based conservation for grassland songbirds in agricultural landscapes. Dissertation, University of Montana, Missoula, USA.

Lwiwski, T. C., N. Koper, and D. C. Henderson. 2015. Stocking rates and vegetation structure, heterogeneity, and community in a northern mixedgrass prairie. Rangeland Ecology \& Management 68:322-331. 
Martin, T. E., C. R. Paine, C. J. Conway, W. M. Hochachka, P. Allen, and W. Jenkins. 1997. BBIRD Field Protocol. Montana Cooperative Wildlife Research Unit, University of Montana, Missoula. Montana, USA. www.fwspubs.org/doi/supp1/10.3996/102016-JFWM-079/suppl_ file/10.3996102016-jfwm-079.s5.pdf. Accessed 22 Nov 2019.

Mielke, P. W., K. J. Berry, and E. S. Johnson. 1976. Multi-response permutation procedures for a priori classifications. Communications in Statistics 5:1409-1424.

Minchin, P. R. 1987. An evaluation of the relative robustness of techniques for ecological ordination. Vegetatio 69:89-107.

Newbold, T., L. N. Hudson, A. P. Arnell, S. Contu, A. De Palma, S Ferrier, S. L. L. Hill, A. J. Hoskins, I. Lysenko, H. R. P. Phillips, et al. 2016. Has land use pushed terrestrial biodiversity beyond the planetary boundary? A global assessment. Science 353:288-291.

Oksanen, J., F. G. Blanchet, R. Kindt, P. Legendre, P. R. Minchin, R. B. O'Hara, G. L. Simpson, P. Solymos, M. H. H. Stevens, and H. Wagner. 2016. Community Ecology Package. https://github.com/vegandevs/ vegan. Accessed 11 May 2016.

Pärtel, M., R. Szava-Kovats, and M. Zobel. 2011. Dark diversity: shedding light on absent species. Trends in Ecology \& Evolution 26:124-128.

Potvin, M. A., and A. T. Harrison. 1984. Vegetation and litter changes of a Nebraska Sandhills prairie protected from grazing. Journal of Range Management 37:55-58.

Ranellucci, C. L., N. Koper, and D. C. Henderson. 2012. Twice-over rotational grazing and its impacts on grassland songbird abundance and habitat structure. Rangeland Ecology \& Management 65:109-118.

Reece, P. E., W. H. Schacht, and J. D. Volesky. 2007. Skillful grazing management on semiarid rangelands. University of Nebraska, Lincoln, USA

Reece, P. E., J. D. Volesky, and W. H. Schacht. 2008. Integrating management objectives and grazing strategies on semi-arid rangeland. University of Nebraska Extension, Lincoln, USA.

Robel, R. J., J. N. Briggs, A. D. Dayton, and L. C. Hulbert. 1970. Relationships between visual obstruction measurements and weight of grassland vegetation. Journal of Range Management 23:295-297.

Rosenberg, K. V., A. M. Dokter, P. J. Blancher, J. R. Sauer, A. C. Smith, P. A. Smith, J. C. Stanton, A. Panjabi, L. Helft, M. Parr, et al. 2019. Decline of the North American avifauna. Science 366:120-124.

Sauer, J. R., D. K. Niven, J. E. Hines, D. J. Ziolkowski, Jr., K. L. Pardieck, J. E. Fallon, and W. A. Link. 2017. The North American Breeding Bird Survey, results and analysis 1966-2015, version 2.07.2017. U.S. Geological Survey Patuxent Wildlife Research Center, Laurel, Maryland, USA.

Scasta, J. D., E. T. Thacker, T. J. Hovick, D. M. Engle, B. W. Allred, S. D. Fuhlendorf, and J. R. Weir. 2015. Patch-burn grazing (PBG) as a livestock management alternative for fire-prone ecosystems of North America. Renewable Agriculture and Food Systems 31:550-567.
Schacht, W. H., J. D. Volesky, D. E. Bauer, and M. B. Stephenson. 2011. Grazing systems for Nebraska Sandhills rangeland. University of Nebraska, Lincoln, USA.

Skagen, S. K., and A. A. Yackel Adams. 2010. Are there optimal densities for prairie birds? Condor 112:8-14

Sliwinski, M. S., M. E. Burbach, L. A. Powell, and W. H. Schacht. 2018a. Factors influencing ranchers' intentions to manage for vegetation heterogeneity and promote cross-boundary management in the northern Great Plains. Ecology and Society 23(4):45.

Sliwinski, M., M. Burbach, L. Powell, and W. Schacht. 2018b. Ranchers' perceptions of vegetation heterogeneity in the northern Great Plains. Great Plains Research 28:185-197.

Sliwinski, M., L. Powell, and W. Schacht. 2018c. Grazing systems do not affect bird habitat on a Sandhills landscape. Rangeland Ecology and Management 72:136-144.e4.

Toombs, T. P., J. D. Derner, D. J. Augustine, B. Krueger, and S. Gallagher. 2010. Managing for biodiversity and livestock. Rangelands 32:10-15.

Toombs, T. P., and M. G. Roberts. 2009. Are Natural Resources Conservation Service range management investments working at crosspurposes with wildlife habitat goals on western United States rangelands? Rangeland Ecology \& Management 62:351-355.

Towne, E. G., D. C. Hartnett, and R. C. Cochran. 2005. Vegetation trends in tallgrass prairie from bison and cattle grazing. Ecological Applications 15:1550-1559.

Vallentine, J. F. 2001. Grazing management. Second edition. Academic Press, San Diego, California, USA

Vermeire, L. T., R. K. Heitschmidt, and M. R. Haferkamp. 2008. Vegetation response to seven grazing treatments in the Northern Great Plains. Agriculture, Ecosystems and Environment 125:111-119.

Winter, S. L., S. D. Fuhlendorf, C. L. Goad, C. A. Davis, K. R. Hickman, and D. M. Leslie, Jr. 2012. Restoration of the fire-grazing interaction in Artemisia filifolia shrubland. Journal of Applied Ecology 49:242-250.

With, K. A., A. W. King, and W. E. Jensen. 2008. Remaining large grasslands may not be sufficient to prevent grassland bird declines. Biological Conservation 141:3152-3167.

Associate Editor: Bill Block.

\section{SUPPORTING INFORMATION}

Additional supporting information may be found in the online version of this article at the publisher's website. 